\title{
FAKTOR-FAKTOR YANG MEMENGARUHI PERILAKU PERAWAT DALAM PEMILAHAN LIMBAH MEDIS DI RS AL ISLAM BANDUNG
}

\author{
Surdiyah Asriningrum \\ ${ }^{1}$ Politeknik Al Islam Bandung \\ surdiyahningrum@gmail.com
}

\begin{abstract}
ABSTRAK
Pemilahan limbah medis di RS Al Islam Bandung belum dapat dilaksanakan sepenuhnya, hal ini berdasarkan dari hasil nilai kepatuhan dalam pemilahan limbah pada tahun 2016 yang dilakukan oleh Bidang Rumah Tangga dan PSPPRS (Pemeliharaan Sarana dan Prasarana dan Peralatan Rumah Sakit) diperoleh nilai $88,37 \%$. Penelitian ini bertujuan untuk mengetahui, mendeskripsikan dan menganalisis pengaruh niat, dukungan sosial, informasi kesehatan atau fasilitas kesehatan, otonomi pribadi dan situasi untuk bertindak secara simultan terhadap perilaku perawat. Populasi dalam penelitian ini adalah 465 perawat, dengan 40 sampel menggunakan teknik proporsional random sampling. Instrumen pengumpulan data menggunakan pertanyaan dengan skala likert dari berbagai teori dan membentuknya menjadi variabel operasi, instrumen tersebut memakai validitas dan realibilitas yang dapat diandalkan sehingga membentuk instrumen asli. Hasil analisis statistik menunjukkan bahwa korelasi antara niat $(\mathrm{X} 1)=-11 \%$, dukungan sosial $(\mathrm{X} 2)=0,31 \%$, informasi kesehatan atau fasilitas kesehatan $(\mathrm{X} 3)=1,1 \%$, otonomi pribadi $(X 4)=-0,01 \%$ dan situasi untuk bertindak $(X 5)=0,003 \%$, variabel tersebut memiliki hubungan yang positif dalam mempengaruhi perubahan perilaku perawat.
\end{abstract}

Kata kunci : Niat, dukungan sosial, informasi kesehatan atau fasilitas kesehatan, otonomi pribadi, situasi untuk bertindak

\begin{abstract}
The separation of medical waste in Al Islam Hospital Bandung can not be fully implemented, it is based on the result of compliance value in waste segregation in 2016 which done by Household Sector and PSPPRS (Maintenance of Facilities and Infrastructure and Hospital Equipment) obtained 88,37\%. This study aims to know, describe and analyze the influence of intention, social support, health information or health facilities, personal autonomy and the situation to act simultaneously on the behavior of nurses. The population of this research is 465 nurse which 40 sample taken using proportional random sampling technique. Data collecting instrumentusing quetionwith likert scale from various theory and form it into operation variable, which validity and reliable test taken to define the original of instrument form. The result statistik
\end{abstract}


analysis showed that the correlation betwen intention $(X 1)=-11 \%$, social support $(X 2)=0,31 \%$, health information or health facility $(X 3)=$ $1,1 \%$, personal autonomy $(X 4)=-0,01 \%$ and situation to act $(X 5)=$ $0,003 \%$, that variable has a positif relation in influencing behavior change of nurse.

Keywords : behaviour intention, social support, accessebility of information, personal autonomy, action situation

\section{PENDAHULUAN}

Pembangunan sektor industri di Indonesia terus mengalami perkembangan, ditunjukkan dengan kegiatan perekonomian yang mengalami peningkatan. Perkembangan ini sebanding dengan penyerapan tenaga kerja yang juga mengalami peningkatan. Pada Agustus 2017 kenaikan jumlah tenaga kerja di Jawa Barat terutama di sektor perdagangan, rumah makan dan jasa akomodasi sebanyak 604,73 ribu orang (11,33\%), Sektor industri sebanyak 300,83 ribu orang $(7,74 \%)$, dan Sektor Jasa kemasyarakatan, sosial dan perorangan sebanyak 206,32 ribu orang $(6,26 \%)$ (BPPAPD, 2017). Penyerapan tenaga kerja ini diharapkan berdampak positif terhadap kesejahteraan di setiap lapisan masyarakat.

Salah satu sektor industri yang mendukung peningkatan ekonomi adalah industri rumah sakit (DepKes, 2015). Peningkatan jumlah pembangunan rumah sakit di indonesia berimplikasi kepada kenaikan jumlah tenaga kerja. Berdasarkan data yang diperoleh dari Profil Kesehatan Indonesia tahun 2016 jumlah rumah sakit di Indonesia sebanyak 2.601 rumah sakit yang terbagi menjadi rumah sakit publik dan rumah sakit privat. Jumlah rumah sakit di seluruh kabupaten atau kota di Jawa Barat pada tahun 2017 sebanyak 328 rumah sakit, di wilayah Bandung sebanyak 35 rumah sakit. Rumah sakit di Indonesia dikelola oleh Kementrian Kesehatan, Pemerintah Provinsi, Pemerintah Kabupaten/Kota,TNI/POLRI, kementrian lain serta swasta non profit. (organisasi sosial dan keagamaan). Rumah sakit privat dikelola oleh Badan Usaha Miliki Negara (BUMN) dan swasta.

Limbah rumah sakit menurut KEPMENKES No.1204/MENKES/SK/X/2004 adalah semua limbah yang dihasilkan oleh kegiatan rumah sakit dan kegiatan penunjang lainnya dalam bentuk padat, cair dan gas. Limbah padat rumah sakit adalah semua limbah rumah sakit yang berbentuk padat sebagai akibat kegiatan rumah sakit yang terdiri atas limbah medis padat dan non medis. Limbah medis padat adalah limbah yang terdiri dari limbah infeksius, limbah patologi, limbah benda tajam, limbah farmasi, limbah sitotoksis, limbah kimiawi, limbah radioaktif, limbah kontainer bertekanan, dan limbah dengan kandungan logam berat yang tinggi.

Dampak dari limbah rumah sakit terhadap lingkungan adalah menurunnya kualitas sanitasi lingkungan dan terjadinya perubahan rona lingkungan di sekitar rumah sakit (Adisasmito, 2012). Limbah infeksius mengandung berbagai jenis patogen yang berpotensi menyebabkan penyakit menular seperti tetanus, infeksi luka, cholera, penyakit diare, infeksi HIV,HBV, HCV dan tuberculosis jika tidak dikelola dengan benar (Zarin and Ahmed, 2009 dalam Hussain, 2014). Pada periode 1996 hingga 2004, di Inggris sebanyak 2140 orang terpapar darah yang mengandung virus dan $21 \%$ luka yang terjadi selama proses pembuangan. Penelitian di Mexico 34\% luka akibat jarum suntik dan 96\% telah bersentuhan dengan jarum suntik dan needle (Acharya et al.,2014).

Rumah Sakit Al-Islam (RSAI) adalah rumah sakit yang berlokasi di wilayah Bandung Timur dan sudah dioperasionalkan selama 27 tahun. Jumlah limbah medis yang 
dikelola oleh RSAI pada periode Tahun 2017 sekitar 52.990,35 kg, sedangkan jumlah limbah cair $200 \mathrm{~m}^{3} /$ hari. Limbah medis padat yang dihasilkan oleh RSAI dikumpulkan di TPS yang kemudian diambil dan dikelola oleh PT Tenang Jaya Sejahtera. Lokasi penempatan limbah medis di ruang rawat inap berada di spoel hoek, bila ada tindakan, pembuangan limbah medis diletakkan di troli sebelum dikumpulkan di spoel hoek.

Perawat sangat berperan terhadap perlakuan limbah medis pertama kali. Peran ini ditunjukkan dengan pelayanan keperawatan kepada pasien seperti menyuntik, memasang selang infus, mengganti cairan infus, memasang selang urin, perawatan luka kepada pasien, dan perawatan dalam pemberian obat (Muchsin, 2013). Perawat berperan dalam menyimpan alat-alat medis sementara yang sudah tidak terpakai lagi, sebelum dikumpulkan dan diangkut ke tempat pembuangan akhir yaitu incinerator oleh petugas pengangkut limbah rumah sakit. Saat pelaksanaannya, masih banyak percampuran antara sampah medis dan non medis di tempat penampungan sampah sementara. Berdasarkan hasil penelitian (Omofunmi et al.,2016) hampir di setiap tempat sampah ditemukan tercampurnya bekas dan sisa makanan (limbah organik), limbah infeksius, dan limbah organik berupa botol bekas infus, kesadaran dalam hal pemilahan dan pewadahan limbah medis masih kurang dan tidak ada dorongan yang kuat perawat dalam berperilaku positif. Berdasarkan hasil observasi pendahuluan di RS Al Islam kebijakan tentang pemilahan limbah medis, pengawasan serta fasilitas pembuangan limbah sudah sesuai aturan KEPMENKES No.1204/MENKES/SK/X/2004, tetapi masih terdapat ditemukannya limbah medis yang tercampur dengan limbah non medis. Pemilahan limbah ini merupakan prosedur yang wajib dilakukan oleh suatu organisasi dalam kasus ini yaitu Rumah Sakit Al-Islam (RSAI). Hasil evaluasi kepatuhan dalam pemilahan dan pengolahan limbah padat berbahaya tahun 2016 yang dilakukan oleh Bidang Rumah Tangga dan PSPPRS (Pemeliharaan Sarana dan Prasarana dan Peralatan Rumah Sakit) RSAI diperoleh nilai kepatuhan $88,37 \%$, maka dapat disimpulkan bahwa masih ditemukan tercampurnya limbah medis dengan limbah non medis. Menurut teori Scnehandu B.Kar bahwa faktor-faktor yang memengaruhi perubahan perilaku terdiri atas : niat, dukungan sosial, informasi kesehatan atau fasilitas kesehatan, otonomi pribadi dan situasi untuk berindak. Berdasarkan uraian di atas, maka rumusan masalah dalam penelitian ini adalah: (1) Bagaimana perilaku perawat dalam pemilahan limbah medis di RS Al Islam Bandung? (2) Faktor-faktor apa saja yang dominan memengaruhi perilaku perawat dalam memilah limbah medis?. Sedangkan tujuan yang ingin dicapai adalah : (1) Untuk mengetahui perilaku perawat dalam pemilahan limbah medis di RS Al Islam Bandung. (2) Untuk mengetahui faktor-faktor apa saja yang dominan memengaruhi perilaku perawat dalam memilah limbah medis.

\section{TINJAUAN TEORITIS}

\section{Limbah Rumah Sakit}

Rumah sakit merupakan salah satu organisasi yang besar karena di dalamnya terdiri atas berbagai macam multi disiplin ilmu yang saling terkait satu dengan yang lainnya seperti kedokteran, perawatan, teknik, ekonomi, hukum maupun humas dan rumah sakit juga memiliki kegiatan yang sangat kompleks meliputi kegiatan rawat jalan, rawat inap, pemeriksaan penunjang seperti laboratorium, radiologi, patologi, kedokteran nuklir serta kamar operasi dan sebagainya. Oleh karena itu semua yang ada di rumah sakit baik ilmu dan kegiatan yang dijalankan oleh sekumpulan orang-orang harus saling bekerjasama untuk mencapai tujuan yang telah ditentukan (Akdon, 2011).

Dari hasil kegiatan yang ada di rumah sakit mulai dari diagnosa, analisis, dan pengobatan pasien tentu menghasilkan banyak limbah, salah satunya limbah medis padat.

Teras Kesehatan -41 
Pengertian limbah secara umum adalah limbah yang berupa padat, cair atau gas. Limbah dianggap berbahaya jika memiliki karakteristik yaitu: mudah terbakar, mudah bereaksi, mudah meledak, mudah berkarat, radioaktif, infeksius, mudah mengiritasi, dan bioakumulasi (LaGrega, 2001 dalam Shareefdeen, 2012). Limbah medis termasuk ke dalam limbah infeksius dan berbahaya yang dihasilkan oleh rumah sakit, klinik dan laboratorium.

Dari hasil kegiatan yang ada di rumah sakit mulai dari diagnosa, analisis, dan pengobatan pasien tentu menghasilkan banyak limbah, salah satunya limbah padat. Pada penelitian yang dilakukan oleh Kumar et al., (2010) dalam Ahmad, (2015) pada tahun 2005 rumah sakit di Pakistan menghasilkan limbah sekitar 250.000 ton per tahunnya, dimana sistem manajemen pengolahan limbah masih belum sesuai standar yang telah ditentukan WHO atau standar peraturan limbah tahun 2005 di Pakistan, akibatnya pasien yang terdapat di rumah sakit, petugas limbah medis, masyarakat umum, dan sanitasi kesehatan lingkungan dapat terkena dampak akibat tercemarnya limbah medis. Oleh karena itu managemen pengelolaan limbah medis dan teknik pengontrolan sangat penting dilakukan.

Limbah rumah sakit menurut KEPMENKES No.1204/MENKES/SK/X/2004 adalah semua limbah yang dihasilkan oleh kegiatan rumah sakit dan kegiatan penunjang lainnya dalam bentuk padat, cair dan gas. Bahan yang digunakan untuk pengobatan pasien yang terinfeksi akan menghasilkan limbah medis infeksius, yang bila pengolahannya tercampur dengan limbah umum, maka limbah umum menjadi limbah infeksius.

Berdasarkan pengertian limbah diatas, Anon (2006) dalam Mohankumar (2010) membagi jenis limbah rumah sakit dalam dua kelompok yaitu limbah non infeksius dan limbah infeksius. Limbah non infeksius terdiri atas limbah dapur dan limbah kantor, seperti limbah makanan, plastik, kertas. Limbah ini sama dengan limbah rumah tangga. Limbah non infeksius paling banyak dihasilkan oleh rumah sakit, hampir sekitar $80 \%$ sampai $85 \%$ dari total limbah dihasilkan dari unit perawatan kesehatan. Limbah infeksius adalah limbah yang mengandung mikroorganisme penyakit. Limbah infeksiur terdiri atas: (1) limbah benda tajam seperti jarum suntik untuk intravena, spuit, infus set, pisau bedah, pipet, pisau, pecahan kaca, (2) limbah patologi adalah jaringan, organ atau cairan manusia, bagian tubuh atau darah yang tidak terpakai lagi, (3) limbah kimia, limbah yang mengandung bahan kimia ( misalnya reagen bahan kimia, cairan developer, cairan desinfektan yang sudah kadaluarsa atau tidak diperlukan lagi, pelarut, limbah dengan kandungan logam berat tinggi misalnya baterai, thermometer dan alat pengukur tekanan darah yang rusak), (4) limbah farmasi, limbah farmasi adalah obat-obatan yang kadaluarsa atau tidak diperlukan lagi, barang yang terkontaminasi oleh atau obat-obatan, limbah sitotoksik yang mengandung zat genotoksik, (5) limbah radioaktif, limbah yang mengandung zat radioaktif misalnya cairan yang tidak terpakai dari radioterapi atau penelitian laboratorium, urin dan ekskreta dari pasien yang diobati atau diuji dengan radionuklida yang tidak disegel ( Pruss, 1999 dalam Acharya, 2014). Jumlah limbah infeksius sekitar 15\% sampai $20 \%$ dari total limbah yang dihasilkan dari perawatan kesehatan. Limbah infeksius mengandung bahan pathogen (bakteri, virus, parasit atau jamur), yang bila pengelolaannya masih belum sesuai standar akan menjadi penyebab penyebaran beberapa penyakit menular.

Pengelolaan yang tepat sangat penting untuk menjaga higienis, estetika, kebersihan, dan pengendalian pencemaran lingkungan. Jika limbah medis yang tidak dikelola dengan baik dapat mencemari tanah, udara dan air. Selanjutnya, dapat menyebabkan penyakit mematikan, baik yang endemik, sporadis atau bentuk epidemi (Pandey, 2010). Pengelolaan limbah yang aman dan efektif tidak hanya merupakan kebutuhan hukum tapi juga tanggung jawab sosial. Tanggung jawab sosial seperti kurangnya keperdulian, motivasi, kesadaran dan faktor biaya adalah beberapa masalah yang dihadapi dalam manajemen limbah rumah sakit 
yang baik serta kebutuhan untuk pengetahuan dan pelatihan mengenai bahaya yang terkait dengan pembuangan limbah yang tidak tepat.

Pengelolaan limbah medis merupakan bagian dari kegiatan penyehatan lingkungan di rumah sakit, maka limbah yang sudah tidak terpakai dibuang pada wadah berdasarkan karakteristik jenis limbah, agar limbah medis tidak tercampur dengan limbah non medis, hal ini sesuai dengan peraturan KEPMENKES No.1204/MENKES/SK/X/2004 di bawah ini ( Tabel 1).

Tabel 1. Jenis wadah dan label limbah medis padat sesuai kategorinya

\begin{tabular}{|c|c|c|c|c|}
\hline No & Kategori & $\begin{array}{l}\text { Warna } \\
\text { Kantung } \\
\text { plastik }\end{array}$ & Lambang & Keterangan \\
\hline 1 & Radioaktif & Merah & & $\begin{array}{l}\text { Kantong boks timbal dengan } \\
\text { simbol radioaktif }\end{array}$ \\
\hline 2 & Infeksius & Kuning & & $\begin{array}{l}\text { Kantong plastik kuat, anti bocor } \\
\text { atau kontainer yang dapat } \\
\text { disterilisasi dengan oloktaf }\end{array}$ \\
\hline 3 & $\begin{array}{l}\text { Limbah } \\
\text { infeksius, } \\
\text { patologi } \\
\text { dan } \\
\text { anatomi }\end{array}$ & Kuning & & $\begin{array}{l}\text { Kantong plastik kuat, anti bocor } \\
\text { atau kontainer }\end{array}$ \\
\hline 4 & Sitotoksis & Ungu & & Kantong plastik kuat, anti bocor \\
\hline 5 & $\begin{array}{l}\text { Limbah } \\
\text { kimia dan } \\
\text { farmasi }\end{array}$ & Coklat & & Kantong plastik atau kontainer \\
\hline
\end{tabular}

Sumber : No.1204/MENKES/SK/X/2004

\section{Perilaku Kesehatan}

Menurut Skinner (1938) dalam Notoatmodjo (2010) perilaku merupakan respons atau reaksi seseorang terhadap stimulus (rangsangan dari luar). Teori Skiner ini dikenal sebagai teori S-O-R (Stimulus-Organisme-Respon). Namun kekurangan pada teori ini, setiap stimulus yang diterima oleh organisme tidak selamanya menghasilkan respon. Definisi lain tentang perilaku yaitu gerakan terbuka yang dapat diamati dari organisme termasuk di dalamnya perilaku verbal serta gerakan fisik Menurut definisi ini perilaku pada dasarnya adalah aktivitas fisik yang dapat diamati. Definisi ini sesuai dengan yang dikemukakan oleh Robert Kwick (1974) dalam Kholid (2012). Adanya perubahan perilaku dipengaruhi juga oleh proses-proses mental, pengaruh-pengaruh sosial serta pengaruh-pengaruh kultural dan keterlibatan komunitas (Graeff, 1996).

Teori yang membahas tentang perilaku manusia terus mengalami perkembangan. Salah satu teori yang digunakan untuk mengetahui tentang ilmu perubahan perilaku adalah Theory of Reasoned Action (TRA) yang dikemukakan oleh Fishbein dan Ajzen (1975), 
menurut model TRA ini perubahan perilaku dipengaruhi oleh 2 faktor yaitu attitude atau sikap dan norma subjektif. Namun pada teori ini masih terdapat kelemahan hubungan antara sikap dan perilaku kemudian teori ini dikembangkan oleh Ajzen (1985) menjadi Theory of Planned Behavior (TPB) untuk memahami dan memprediksi perilaku individu secara lebih spesifik. Dalam TPB, anteseden dalam perubahan perilaku adalah "niat" untuk melakukan perilaku. Niat ditentukan oleh keyakinan perilaku yang akhirnya menimbulkan persepsi positif atau konsekuensi negatif dan nilai subjektif atau evaluasi dari konsekuen. Oleh karena itu niat merupakan sebagai motivasi untuk melakukan sesuatu (Ajzen, 2015). Theory of Planned Behavior (TPB) merupakan teori pelengkap dari teori yang sebelumnya yaitu Theory of Reasoned Action Faktor-faktor TPB terdiri atas attitudes atau sikap, subjective norms atau norma subjektif, dan perceived behavioural control atau kontrol perilaku. Untuk lebih memahami faktor-faktor attitude, norma subjektif, dan kontrol perilaku dapat dilihat pada diagram Theory of Planned Behavior (Gambar 1)

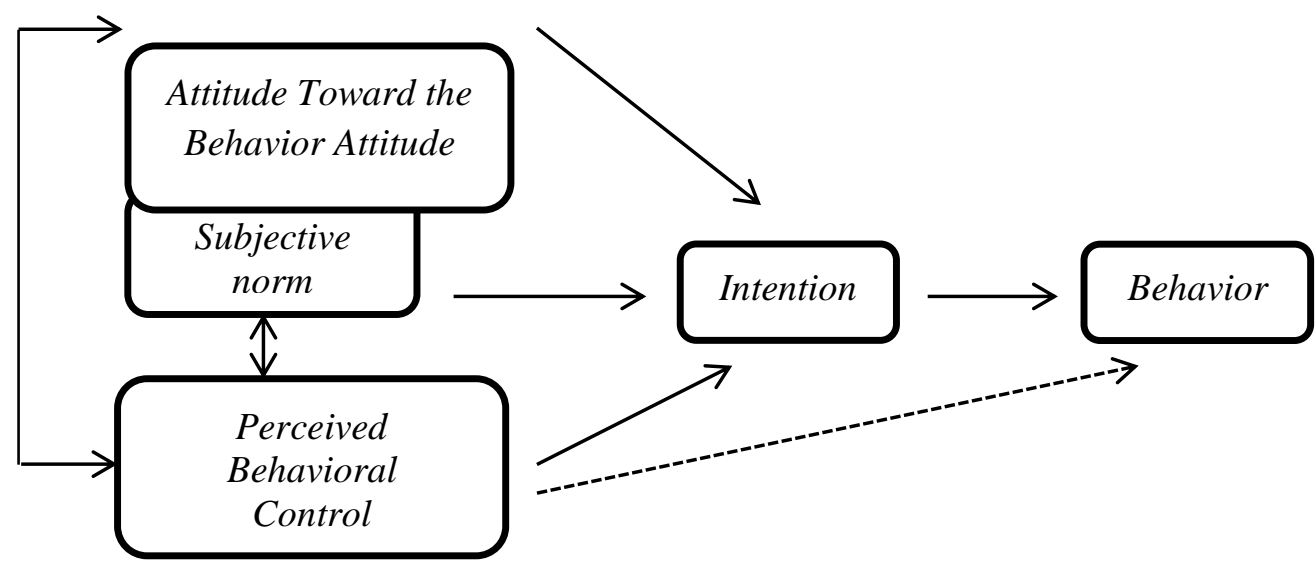

Gambar 1. Theory of Planned Behavior (Sumber Ajzen, 2005 dalam Ramdhani, 2011)

Faktor-faktor yang mempengaruhi perilaku menurut teori Theory of Planned Behavior, yaitu : (1) Attitude Toward the Behavior Attitude. Ajzen (2005) dalam Ramdhani (2011) mengemukakan bahwa sikap terhadap perilaku ini ditentukan oleh keyakinan mengenai konsekuensi dari suatu perilaku (behavioral beliefs). Keyakinan ini didapat dari pemahaman terhadap dunia sekitarnya, pemahaman diri dan lingkungannya, kemudian menghubungkan antara perilaku tertentu dengan berbagai manfaat atau kerugian yang mungkin diperoleh apabila individu melakukan atau tidak melakukannya. Keyakinan yang ada pada diri ini dapat memperkuat sikap terhadap perilaku apabila berdasarkan evaluasi dapat memberikan hal yang positif yang dilakukan individu, (2) norma subjektif adalah faktor dukungan sosial yang dapat mempengruhi dilakukan atau tidak dilakukannya perilaku tertentu. Persepsi ini sifatnya subjektif sehingga dimensi ini disebut norma subjektif. Sebagaimana sikap terhadap perilaku, norma subjektif juga dipengaruhi oleh keyakinan pandangan orang-orang lain terhadap sikap yang berhubungan dengan individu (normative belief) (Bilic, 2005), (3) persepsi kontrol perilaku atau dapat disebut dengan kontrol perilaku adalah keyakinan individu akan berhasil menguasai keterampilan yang dibutuhkan untuk menyelesaikan tugas-tugas tertentu (Bandura, 1977; Pajares, 1996 dalam Ramdhani 2011). Keyakinan ini ditentukan juga oleh adanya ketersediaan sumber daya berupa peralatan, kompatibelitas, kompetensi dan kesempatan yang mendukung atau menghambat perilaku yang akan diprediksi dan besarnya perubahan perilaku tersebut Persepsi kontrol yang tinggi akan menimbulkan dorongan yang kuat untuk karena dengan keyakinan dengan sumberdaya dan kesempatan yang ada, kesulitan yang dihadapinya dapat diatasi (Ajzen, 2005 dalam Ramdhani, 2011). 
Salah satu teori yang menjelaskan tentang perubahan perilaku adalah Teori Snehandu B.Kar. Teori ini mencoba untuk menganalisis perilaku kesehatan dengan bertitik tolak bahwa perilaku merupakan fungsi dari : (1) niat, niat merupakan faktor yang paling utama dalam merubah perilaku dalam hal ini adalah motivasi seseorang untuk bertindak sehubungan dengan kesehatan atau perawatan kesehatannya (behaviour intention) terdiri atas : sikap, norma subjektif, dan kontrol perilaku, (2) dukungan sosial dari masyarakat sekitarnya (social support). Saronson (1991) menerangkan bahwa dukungan sosial dapat dianggap sebagai sesuatu keadaan yang bermanfaat bagi individu yang diperoleh dari orangorang yang dapat dipercaya. Adapun aspek-aspek dukungan sosial menurut Sarafino (1998) dalam Rahmadita (2013) adalah berupa dukungan emosional, penghargaan, instrumental, informasi, dan kelompok, (3) ada atau tidak adanya informasi tentang kesehatan atau fasilitas kesehatan (accessebility of information). Faktor ini mencakup ketersediaan sarana dan prasarana atau fasilitas kesehatan, (4) otonomi pribadi yang bersangkutan dalam hal ini mengambil tindakan atau keputusan (personal autonomy). Otonomi adalah tingkat dimana suatu pekerjaan memberikan kebebasan, kemandirian serta keleluasaan substansil bagi pekerja dalam menjadwalkan pekerjaannya dan dalam menentukan prosedur yang digunakan dalam menyelesaikan pekerjaan ( Wexley, 1988), (5) situasi yang memungkinkan untuk bertindak atau tidak bertindak (action situation).

Uraian di atas dapat dirumuskan sebagai berikut

$$
\begin{aligned}
& \mathrm{B}=\mathrm{f}(\mathrm{BI}, \mathrm{SS}, \mathrm{AL}, \mathrm{PA}, \mathrm{AS}) \\
& \text { Keterangan }: \\
& \mathrm{B}=\text { Perilaku } \\
& \mathrm{F}=\text { Fungsi } \\
& \mathrm{BI}=\text { Niat } \\
& \mathrm{SS}=\text { Dukungan sosial } \\
& \mathrm{AI}=\text { Informasi kesehatan } \\
& \mathrm{PA}=\text { Otonomi pribadi } \\
& \mathrm{AS}=\text { Situasi yang memungkinkan untuk bertindak }
\end{aligned}
$$

\subsubsection{Sistem Manajemen Perubahan Perilaku}

Dalam program-program kebijakan rumah sakit tentang pemilahan limbah medis, supaya diperoleh perubahan perilaku yang sesuai dengan norma-norma kesehatan. Adapun perubahan perilaku tersebut diharapkan sanitasi lingkungan tetap terjaga dan tidak menjadi sumber penyakit, menjadi sangat diperlukan usaha-usaha konkret dan positif. Teori-teori yang mendukung perubahan perilaku disertai dengan sistem managemen yang baik akan memberikan dukungan positif yang sangat kuat terhadap terjadinya perubahan perilaku.

Perubahan perilaku ke arah yang lebih baik adalah tujuan setiap organisasi dengan melakukan analisis dan evaluasi untuk mengungkap permasalahan yang ada pada setiap kegiatan dan melakukan tindakan perbaikan secara terus menerus sehingga menjadi organisasi yang unggul. Salah satu analisis yang digunakan untuk mengetahui permasalahan dan solusinya adalah dengan menggunakan analisis fishbone (tulang ikan) atau analisis sebab akibat.

Dalam diagram tulang ikan, masalah utama yang harus diselesaikan diletakkan pada kepala diagram dan penyebabnya diletakkan sebagai tulang dan kemudian tulang kecil dibuat sebagai sub sebab. Akhirnya setelah selesainya diagram itu kemudian dievaluasi penyebab 
masalah utama dan juga mengungkapkan akar penyebabnya (Balanced Scorecard Institute, 2007 dalam Bose, 2012).

Diagram tulang ikan pada masalah utama ini adalah perilaku perawat dalam memilah limbah medis dan penyebabnya dengan menggunakan teori perubahan perilaku Snehandu B.Kar. Diagram fishbone dapat dilihat pada gambar dibawah ini.

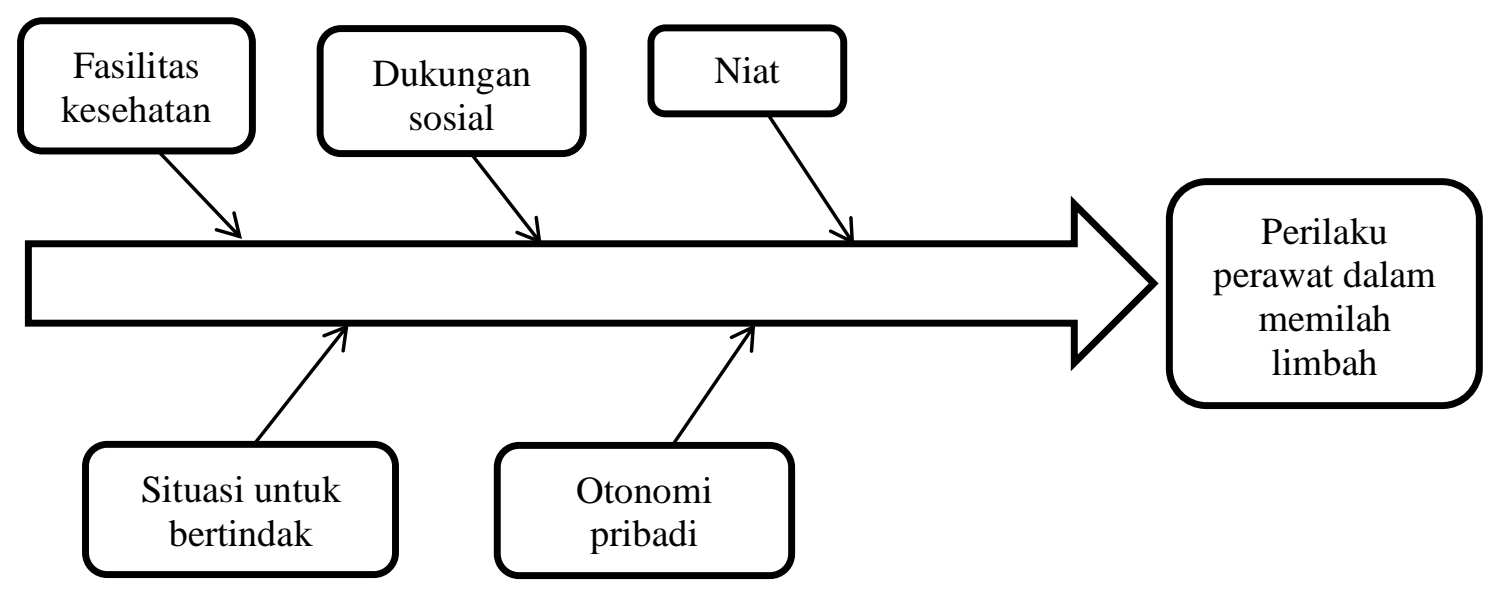

Gambar 2.2 Diagram fishbone hipotesis faktor-faktor penyebab masalah (Bose, 2012)

Catatan : telah diolah kembali

\subsection{Standar Operasional Prosedur (SOP)}

Standar Operasioanl Prosedur adalah Suatu standar atau pedoman tertulis yang dipergunakan untuk mendorong dan menggerakkan suatu kelompok untuk mencapai tujuan organisasi. Standar operasional prosedur merupakan tata cara atau tahapan yang dilakukan dan yang harus dilalui untuk menyelesaikan suatu proses kerja tertentu (Kurnia Anin, 2008 dalam Nahal dan A.Latief, 2014).

Berpedoman kepada SOP pemilahan limbah yang telah ditetapkan rumah sakit dengan tujuan penerapan pemilahan limbah dapat dilakukan oleh perawat dengan didukung fasilitas, sarana dan pendukung lainnya. Namun keberhasilan pelaksanaan SOP tergantung dari perilaku perawat itu sendiri. Dengan meningkatnya pengetahuan serta kompetensi perawat, standar yang telah dibakukan akan terimplementasikan dengan baik sehingga terciptanya keselamatan kerja.

\section{METODE PENELITIAN}

\section{Jenis Penelitian}

Penelitian ini bersifat kuantitatif, yaitu data yang diperoleh dari hasil analis jawaban kuesioner secara statistik. Metode ini digunakan untuk mengetahui faktor-faktor apa saja yang memengaruhi perilaku perawat dalam memilah limbah medis. Data kuantitatif yang telah diperoleh kemudian dianalis sehingga didapat hasil yang komprehensif. Hasil tersebut diuraikan dalam bentuk deskriptif. Data sampel yang diambil dari populasi menggunakan teknik Probability sampling dengan teknik simple random sampling yaitu teknik sampling yang memberi peluang sama kepada anggota populasi untuk dipilih menjadi anggota sampel. 
Berdasarkan data dari sampel tersebut selanjutnya dibuat generalisasi untuk menjawab rumusan masalah (Sugiyono, 2014).

\section{Populasi dan Sampel}

Populasi perawat RSAI sebanyak 465, maka besar sampel minimal 40 orang, ini ditentukan berdasarkan rumus untuk uji hipotesis dengan menggunaan rumus Lynch dengan perhitungan sebagai berikut:

$$
\begin{aligned}
\mathrm{n} & =\frac{\mathrm{N} \cdot \mathrm{Z}^{2} \cdot \mathrm{P}(1-\mathrm{P})}{\mathrm{N} \cdot \mathrm{d}^{2}+\mathrm{Z}^{2} \cdot \mathrm{P}(1-\mathrm{P})} \\
& =\frac{465(1,96)^{2}(0,5)(0,5)}{465(0,5)^{2}+(1,96)^{2}(0,5)(0,5)} \\
& =\frac{446,586}{117,210}=38
\end{aligned}
$$

Dimana : $\mathrm{n}=$ ukuran sampel (responden)

$\mathrm{N}=$ ukuran populasi

$\mathrm{Z}=$ nilai distribusi angka baku $(1,96)$

$\mathrm{d}=$ sampling error $(5 \%)$

$\mathrm{P}=$ proporsi kemungkinan terbesar $(50 \%)$

\section{Uji Reliabilitas}

Pengujian Reliabilitas ini digunakan untuk mengetahui sejauh mana kuesioner yang digunakan dapat dipercaya atau dapat memberikan perolehan hasil penelitian yang konsisten apabila alat ukur ini digunakan kembali dalam pengukuran gejala yang sama.

Metoda yang digunakan dalam pengujian reliabilitas ini adalah dengan menggunakan metode Cronbach's Alpha. Bila nilai Cronbach's Alpha variabel yang diteliti lebih besar dibandingkan dengan dengan nilai $r_{\text {tabel }}$ maka item pertanyaan tersebut adalah reliabel.

\section{Uji Validitas}

Validitas bertujuan mengetahui sejauh mana ketepatan dan kecermatan suatu alat ukur dalam mengukur suatu data. Untuk mengetahui validitas suatu instrumen (kuesioner) dilakukan dengan cara melakukan korelasi antar skor masing-masing variabel dengan skor totalnya. Suatu variabel (pertanyaan) dikatakan valid bila skor variabel tersebut berkorelasi secara signifikan dengan skor totalnya.

\section{Variabel Penelitian}

Adapun defenisi operasional variabel yang digunakan dalam penelitian ini dapat dilihat pada tabel di bawah ini.

Tabel 2 Variabel penelitian

\begin{tabular}{|l|l|l|l|l|l|}
\hline \multicolumn{1}{|c|}{ Variabel } & \multicolumn{1}{|c|}{ Definisi } & Cara Ukur & Alat Ukur & Hasil Ukur & Skala Ukur \\
\hline Niat & $\begin{array}{l}\text { motivasi untuk } \\
\text { melakukan sesuatu }\end{array}$ & Angket & Kuesioner & Skor & Interval \\
\hline $\begin{array}{l}\text { Dukungan } \\
\text { sosial dari } \\
\text { masyarakat } \\
\text { sekitar }\end{array}$ & $\begin{array}{l}\text { sesuatu keadaan } \\
\text { yang bermanfaat } \\
\text { bagi individu yang } \\
\text { diperoleh dari } \\
\text { orang- orang yang }\end{array}$ & Angket & Kuesioner & Skor & Interval \\
\hline
\end{tabular}

Teras Kesehatan -47 


\begin{tabular}{|l|l|l|l|l|l|}
\hline & dapat dipercaya & & & & \\
\hline $\begin{array}{l}\text { Informasi } \\
\text { kesehatan } \\
\text { atau fasilitas } \\
\text { kesehatan }\end{array}$ & $\begin{array}{l}\text { ketersediaan dan } \\
\text { sarana } \\
\text { prasarana atau } \\
\text { fasilitas kesehatan }\end{array}$ & Angket & Kuesioner & Skor & Interval \\
\hline $\begin{array}{l}\text { Otonomi } \\
\text { pribadi }\end{array}$ & $\begin{array}{l}\text { mengambil } \\
\text { tindakan atau } \\
\text { keputusan }\end{array}$ & Angket & Kuesioner & Skor & Interval \\
\hline $\begin{array}{l}\text { Situasi untuk } \\
\text { bertindak }\end{array}$ & $\begin{array}{l}\text { Kondisi } \\
\text { lingkungan yang } \\
\text { mendukung untuk } \\
\text { bertindak fisik }\end{array}$ & Angket & Kuesioner & Skor & Interval \\
\hline Perilaku & $\begin{array}{l}\text { Aktivitas } \\
\text { yang dapat diamati }\end{array}$ & & Kuesioner & Skor & Interval \\
\hline
\end{tabular}

\section{Pengolahan dan Analisis Data}

Tujuan dari skala pengukuran ini adalah untuk mengklasifikasikan variabel yang akan diukur supaya tidak terjadi kesalahan dalam menentukan analisis data (Riduwan, 2012). Skala pengukuran untuk mengukur variabel niat, dukungan sosial dari masyarakat sekitar, informasi kesehatan atau fasilitas kesehatan, otonomi pribadi, serta situasi untuk bertindak, dalam penelitian ini digunakan skala likert. Pengukuran sikap dalam skala likert diungkapkan melalui pernyataan yang dijawab oleh responden dengan pilihan sangat setuju (SS), setuju (S), Ragu-ragu (R), tidak setuju (TS), dan sangat tidak setuju (STS). Untuk tiap pernyataan nilai 5 untuk pernyataan sangat setuju (SS), nilai 4 untuk pernyataan setuju (S), nilai 3 untuk ragu-ragu, nilai 2 untuk tidak setuju (TS), dan nilai 1 untuk pernyataan sangat tidak setuju (STS).

Skala pengukuran perilaku perawat dilakukan dengan mengisi pertanyaan berupa prosedur tetap atau kebijakan tentang pemilahan limbah medis di RS Al Islam Bandung. Nilai 1 untuk yang tidak mengetahui prosedur tetap, nilai 1 untuk menjawab 1 prosedur tetap, nilai 2 untuk menjawab 2 prosedur tetap, nilai 3 untuk menjawab 3 prosedur tetap, nilai 4 untuk menjawab 4 prosedur tetap, nilai 5 untuk menjawab 5 prosedur tetap.

Untuk mengetahui faktor-faktor apa saja yang paling memengaruhi perilaku perawat dalam memilah limbah, peneliti mengumpulkan data berupa kuesioner kemudian diolah dan dianalisis dengan menggunakan analisis jalur (path analysis). Pada penelitian path analysis ini, terdapat lima variabel bebas yaitu niat $\left(\mathrm{X}_{1}\right)$, dukungan sosial $\left(\mathrm{X}_{2}\right)$, fasilitas kesehatan $\left(\mathrm{X}_{3}\right)$, otonomi pribadi $\left(\mathrm{X}_{4}\right)$ dan situasi untuk bertindak $\left(\mathrm{X}_{5}\right)$ dan satu variabel terikat yaitu perilaku perawat $(\mathrm{Y})$.

Kemudian data yang terkumpul diolah secara komputerisasi untuk mengubah data menjadi informasi. Adapun langkah-langkah dalam pengolahan data dimulai dari : (1) Editing, yaitu memeriksa kebenaran data yang diperlukan, (2) Coding, yaitu mengubah data berbentuk kalimat atau huruf menjadi data angka atau bilangan, (3) Data entry, yaitu memasukkan data hasil pemeriksaan dan pengukuran subjek penelitian ke daalm program computer, (4) Cleaning, yaitu apabila semua data dari subjek penelitian telah selesai dimasukkan, maka perlu dicek kembali untuk melihat kemungkinan-kemungkinan adanya kesalahan-kesalahan kode, ketidaklengkapan dan sebagainya, kemudian dilakukan koreksi.

Penelitian kuantitatif bertujuan untuk menguji hubungan antar variabel penelitian. Untuk mengetahui faktor-faktor apa saja yang paling memengaruhi perilaku perawat dalam 
memilah limbah, peneliti mengumpulkan data berupa kuesioner kemudian diolah dan dianalisis dengan menggunakan analisis jalur (path analysis).

berdasarkan analisis jalur hubungan antara ke lima variabel bebas $\left(\mathrm{X}_{1}, \mathrm{X}_{2}, \mathrm{X}_{3}, \mathrm{X}_{4}, \mathrm{X}_{5}\right)$ terhadap variabel terikat (Y). Menurut Riduwan dan Kuncoro (2017), analisis ini bertujuan untuk: (1) Penjelasan (explanation) terhadap fenomena yang dipelajari atau permasalahannya, (2) Prediksi nilai variabel terikat (Y) berdasarkan nilai variabel bebas (X), dan prediksi dengan path analysis ini bersifat kualitatif, (3) Faktor diterminan yaitu penentuan variabel bebas (X) mana yang berpengaruh dominan terhadap variabel terikat (Y), (4) Pengujian model, menggunakan teory triming, baik uji reliabilitas konsep yang sudah ada ataupun uji pengembangan konsep baru.

\section{HASIL DAN PEMBAHASAN}

Berdasarkan data di yang didapat diketahui bahwa dari 40 responden yang diteliti laki-laki $(37,5 \%)$ dan perempuan $(62,5 \%)$, dengan demikian dapat disimpulkan bahwa sebagian besar responden yang diteliti adalah perempuan, ditinjau berdasarkan usia, $15 \%$ berkisar antara 22-25 tahun, 17,5\% antara usia $25-30$ tahun, 32,5\% antara usia 30-35, 25\% antara usia 35-40 tahun, dan $10 \%$ antara usia $40-45 \%$.

Ditinjau berdasarkan tingkat pendidikan terakhir dari 40 responden yang diteliti, pendidikan D3 sebanyak 95\%, dan S1 sebanyak 5\%.

Ditinjau dari segi lama kerja, 1-5 tahun sebanyak 30\%, 5-10 tahun 35\%, 10-15 tahun $20 \%$ dan di atas 15 tahun $15 \%$.

Dalam penelitian ini untuk mengetahui faktor-faktor yang memengaruhi pemilahan limbah medis, dilakukan dengan bantuan tools program SPSS for windows versi 16.0 dengan menggunakan teknik path analysis. Variabel dalam penelitian ini terdiri atas variabel bebas (X) yaitu : niat $\left(\mathrm{X}_{1}\right)$, dukungan sosial $\left(\mathrm{X}_{2}\right)$, fasilitas kesehatan $\left(\mathrm{X}_{3}\right)$, otonomi pribadi $\left(\mathrm{X}_{4}\right)$, situasi untuk bertindak atau tidak bertindak $\left(\mathrm{X}_{5}\right)$ dan variabel terikat yaitu perilaku perawat dalam melakukan pemilahan limbah medis (Y).

Untuk melihat berapa persen pengaruh variabel bebas $(X)$ dalam memengaruhi variabel terikat (Y), maka dapat dilihat pada out put model summary.

Tabel 1. Model Summary

\begin{tabular}{ccccc}
\hline Model & $\begin{array}{c}\text { Korelasi } \\
\text { antar } \\
\text { variabel }\end{array}$ & $\begin{array}{c}\text { Koefisien } \\
\text { determinasi }\end{array}$ & $\begin{array}{c}\text { Koefisiensi } \\
\text { determinasi yang } \\
\text { terkoreksi }\end{array}$ & Standar error \\
\hline 1 & 0,373 & 0,139 & 0,13 & 0,38239 \\
\hline
\end{tabular}

Dari hasil output model summary nilai koefisien korelasi secara bersama-sama memiliki hubungan terhadap perubahan perilaku sebesar ( $R$ ) 0,373 , nilai positif ini menunjukkan hubungan variabel tersebut memiliki hubungan yang searah. Nilai variabel mendekati 1 maka hubungan antar variabel semakin kuat. Untuk memperlihatkan sumbangan pengaruh langsung variabel niat, dukungan sosial, fasilitas kesehatan, otonomi pribadi dan situasi untuk bertindak yang diberikan terhadap perilaku (koefisien determinasi atau R Square) didapat nilai $13,9 \%$, sisanya sebesar $86,1 \%$ dipengaruhi oleh faktor lain yang tidak diteliti dalam penelitian ini. 
Hubungan secara individual antara variabel niat, dukungan sosial, fasilitas kesehatan, otonomi pribadi dan situasi untuk bertindak terhadap perilaku secara individual dapat digambar dengan diagram jalur berikut:

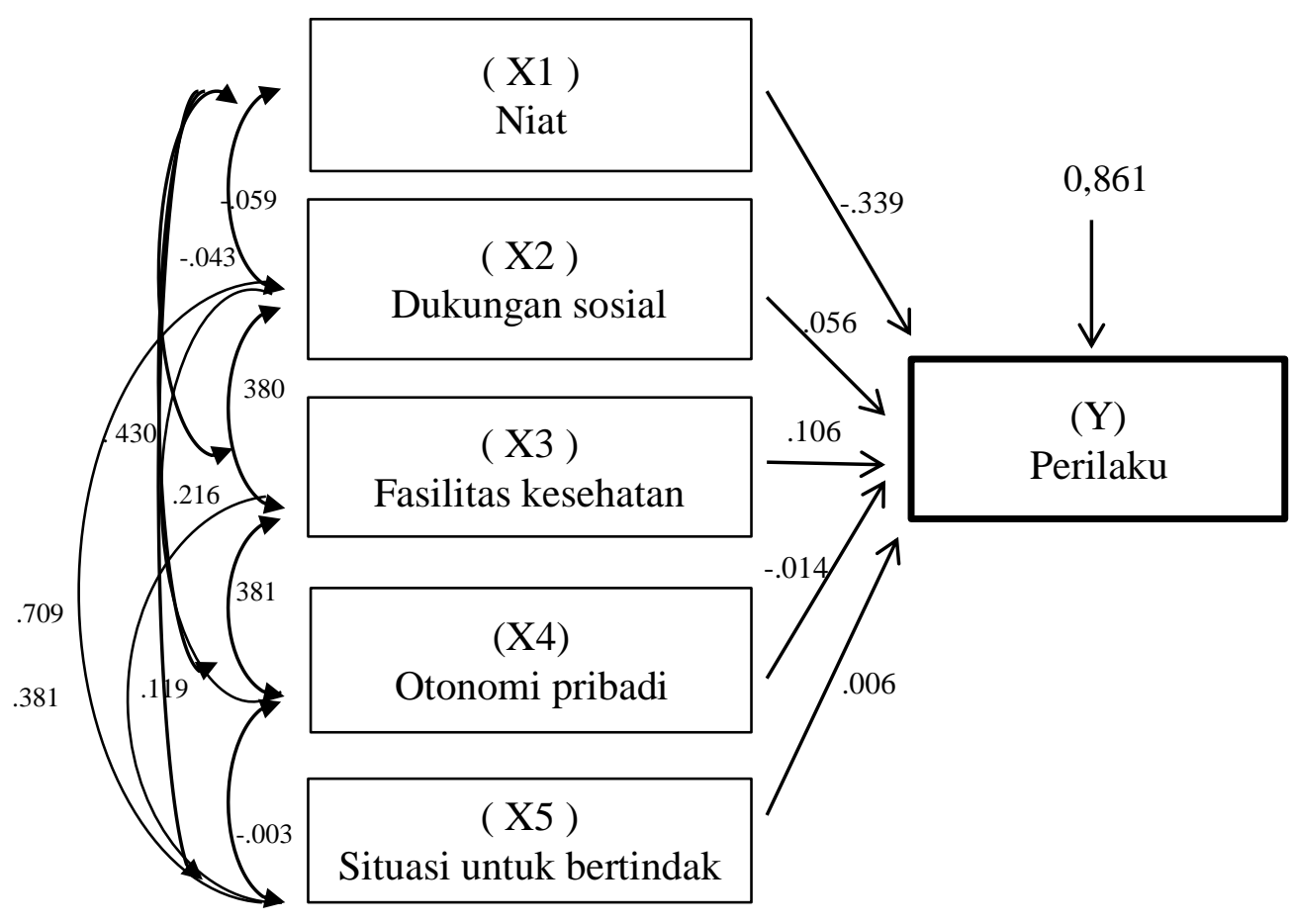

Gambar 1 Hasil analisis jalur

Kerangka hubungan kausal empiris antara X1, X2, X3, X4 dan X5 terhadap Y dapat dibuat melalui persamaan sebagai berikut :

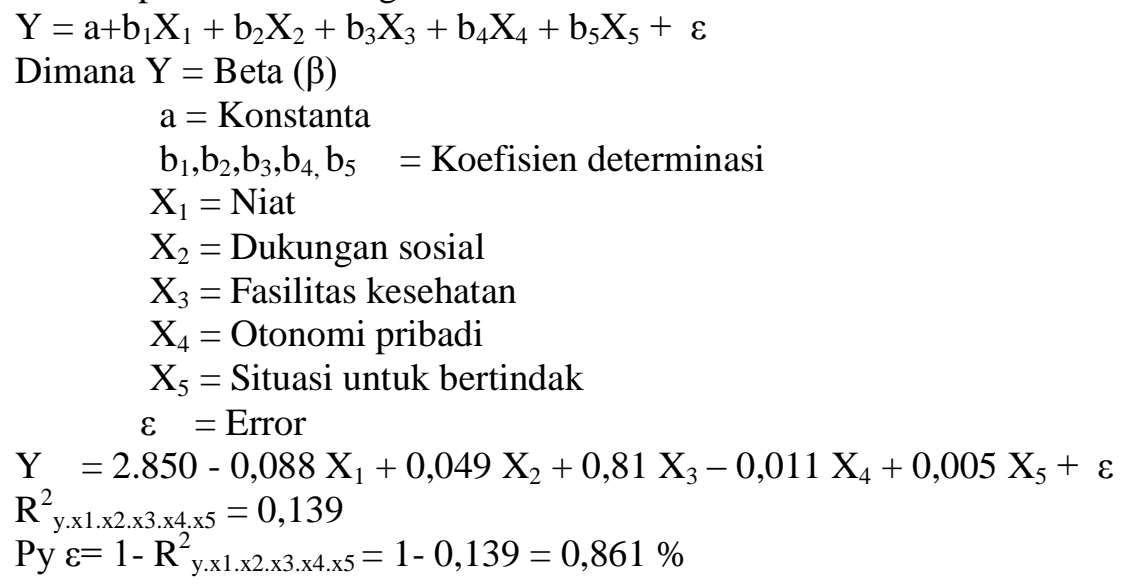

\section{Perilaku perawat dalam memilah limbah medis}

Perilaku perawat dalam memilah limbah medis dinilai dengan menggunakan Prosedur Tetap yang menjadi kebijakan di RS Al Islam Bandung. Dari 40 responden didapat $82,5 \%$ menjalani semua prosedur yang ditetapkan di RS Al Islam Bandung 17,5\% melaksanakan 4 prosedur tetap. 


\section{Hasil Analisis Jalur}

Dalam penelitian ini untuk mengetahui faktor-faktor apa saja yang memengaruhi pemilahan limbah medis, dilakukan dengan bantuan tools program SPSS for windows versi 16.0 Variabel dalam penelitian ini terdiri dari variabel bebas $(\mathrm{X})$ yaitu : niat (X1), dukungan sosial (X2), fasilitas kesehatan (X3), otonomi pribadi (X4), situasi untuk bertindak atau tidak bertindak (X5) dan variabel terikat yaitu perilaku perawat dalam melakukan pemilahan limbah medis (Y).

Hasil penelitian menunjukkan Secara parsial terdapat hubungan negatif dan signifikan antara niat dan otonomi pribadi dengan perubahan perilaku di Rumah Sakit Al Islam Bandung, dengan nilai $\mathrm{R}$ niat $=-0,349$ dan $\mathrm{P}=0,027$ dan nilai $\mathrm{R}$ otonomi pribadi $=$ 0,003 dan $\mathrm{P}=0,984$. Hal ini bermakna adanya hubungan terbalik antara niat dan otonomi pribadi terhadap perubahan perilaku, dimana ketika niat dan otonomi tinggi maka perubahan perilaku menurun. Niat dan otonomi pribadi merupakan sikap yang belum tampak dan belum berupa tindakan. Sikap yang paling tinggi tingkatannya adalah bertanggung jawab terhadap apa yang telah diyakininya. Sikap terdiri dari 3 komponen pokok, yaitu kepercayaan atau keyakinan, ide, dan konsep terhadap objek; kehidupan emosional atau evaluasi orang terhadap objek; dan kecenderungan untuk bertindak (tend to behave). Ketiga komponen tersebut secara bersamasama membentuk sikap yang utuh (total attitude), sehingga peranan pengetahuan, pikiran, keyakinan, dan emosi memegang peranan penting dalam menentukan sikap responden terhadap timbulnya dampak seperti penyakit dan pencemaran lingkungan akibat pengelolaan sampah medis yang kurang baik (Amien A,2015 dkk dalam Fahriyah L, dkk, 2016). Tetapi ketika tuntutan perubahan terlalu tinggi dengan menerapkan disiplin dalam pekerjaan dapat melemahkan hubungan stimulus. Unsur disiplin menurut Hurlock (2002) diantaranya peraturan sebagai pedoman perilaku, konsistensi dalam peraturan, hukuman untuk pelanggaran, penghargaan untuk perilaku baik.

Secara parsial terdapat hubungan positif dan signifikan antara dukungan sosial, fasilitas dan informasi kesehatan dan situasi untuk bertindak dengan perubahan perilaku di Rumah Sakit Islam Bandung, dengan nilai $\mathrm{R}$ dukungan sosial $(\mathrm{X} 2)=0,056$ dengan $\mathrm{P}=$ 0,114 , $\mathrm{R}$ fasilitas atau informasi kesehatan $=0,106$ dengan $\mathrm{P}=0,136$ dan nilai $\mathrm{R}$ situasi untuk bertindak $(X 5)=0,006$ dengan nilai $P=0,039$. Faktor ketersediaan fasilitas merupakan salah satu faktor pendorong pembentukan perilaku (Lawrence Green, 1980 dalam Nurhidayah, 2015). Sejalan dengan penelitian yang dilakukan oleh Nurhidayah (2015) menunjukkan hasil penelitian bahwa ada hubungan yang signifikan ketersediaan fasilitas dengan perilaku p $0,044(<0,05)$. Sejalan dengan penelitian yang dilakukan oleh Sudiharti dkk (2012) tentang tingkat pengetahuan dengan perilaku perawat dalam pembuangan sampah medis di rumah sakit PKU Muhammadiyah terdapat hubungan pengetahuan dengan perilaku perawat dalam pembuangan sampah. Dengan nilai $(\rho)$ yaitu 0,002. Saronson (1991) dalam Rahmadita (2013) menerangkan bahwa dukungan sosial dapat dianggap sebagai sesuatu keadaan yang bermanfaat bagi individu yang diperoleh dari orang-orang yang dapat dipercaya. Dari keadaan tersebut individu akan mengetahui bahwa orang lain memperhatikan, menghargai, dan mencintainya. Menurut Shamila dan Sohail (2013) dalam Adnyaswarin (2017) sumber-sumber dukungan sosial dapat berasal dari keluarga, rekan sekerja, dan atasan. Seorang perawat yang bekerja di rumah sakit diharapkan mendapat dukungan sosial baik dari atasan, teman sekerja, maupun keluarga.

Bentuk dukungan sosial yang terpenting yang harus diberikan kepada perawat yaitu dukungan informatif dan dukungan penghargaan. Hasil penelitian yang dilakukan oleh Adnyaswarin dkk (2017) menunjukkan bahwa nilai signifikan pengaruh dukungan sosial terhadap kinerja karyawan adalah sebesar 0,000 lebih kecil dari 0,05 . Hasil ini menunjukkan bahwa dukungan sosial berpengaruh positif dan signifikan terhadap kinerja karyawan. Hasil

Teras Kesehatan - 51 
uji parsial menunjukan bahwa dukungan sosial berpengaruh positif terhadap kinerja perawat pada bidang rawat inap di RSUP Sanglah Denpasar.

Kemudian untuk menguji variabel independen $\left(\mathrm{X}_{1}, \mathrm{X}_{2}, \mathrm{X}_{3}, \mathrm{X}_{4}, \mathrm{X}_{5}\right)$ secara bersamasama berpengaruh secara signifikan terhadap variabel dependen $(\mathrm{Y})$ maka digunakan uji $\mathrm{F}$ seperti terlihat tabel berikut:

Tabel 2. Analysis of Variance (ANOVA)

\begin{tabular}{llccccc}
\hline Model & $\begin{array}{c}\text { Jumlah } \\
\text { kuadrat }\end{array}$ & df & $\begin{array}{c}\text { Rata-rata } \\
\text { kuadrat }\end{array}$ & F & Sig \\
\hline 1 & Regresi & 0,804 & 5 & 0,161 & 1.099 & 0,379 (a) \\
& Variabel lain & 4.971 & 34 & 0,146 & & \\
\hline & Total & 5.775 & 39 & & & \\
\hline
\end{tabular}

a. Variabel independen: Situasi untuk bertindak $\left(\mathrm{X}_{5}\right)$, Niat $\left(\mathrm{X}_{1}\right)$, Fasilitas kesehatan $\left(\mathrm{X}_{3}\right)$, Otonomi pribadi $\left(\mathrm{X}_{4}\right)$, Dukungan sosial $\left(\mathrm{X}_{2}\right)$

b. Dependent variabel : Perilaku (Y)

Berdasarkan uji Anova atau $\mathrm{F}$ test didapat $\mathrm{F}$ hitung sebesar 1.099 dengan tingkat signifikan 0,379. Karena lebih besar dari 0,05 maka secara statistic model regresi

Memiliki signifikansi lemah atau model regresi yang terbentuk dapat dipakai untuk memprediksi perilaku perawat.

\subsection{Signifikasi Praktis}

Dalam metode Grounded Researches, yaitu model penelitian yang mendasarkan diri kepada fakta dan menggunakan analisa empiris, menetapkan konsep-konsep, membuktikan teori dan mengembangkan teori dimana pengumpulan data dan analisa data berjalan pada waktu bersamaan (Rusdin, 2004). Faktor-faktor yang memengaruhi perubahan perilaku menurut Teori Schenandu B.Kar, terdiri atas: niat, dukungan sosial, fasilitas kesehatan atau informasi kesehatan, otonomi pribadi dan situasi untuk bertindak. Berdasarkan hasil observasi atau tinjauan lapangan di RS Al Islam bahwa faktor-faktor tersebut sudah baik. Adapun gambaran hasil kuesioner responden paling banyak menjawab dengan skor 3 untuk pertanyaan positif dan skor 1 untuk pertanyaan negatif. Hal ini di dukung oleh adanya kegiatan-kegiatan keagamaan, pelatihan yang dapat meningkatkan ilmu tentang limbah medis, fasilitas limbah medis yang disediakan di setiap ruang rawat inap, dukungan sosial, sehingga memberikan kenyamanan perawat dalam bertindak.

\section{KESIMPULAN}

Kebijakan yang sudah dilakukan oleh RS Al Islam Bandung dalam mendukung kebijakan Pemerintah berupa kebijakan pemilahan limbah medis dengan non medis yang harus dipatuhi oleh setiap sumber daya yang dimiliki dan adanya fasilitas untuk mendukung kegiatan tersebut. Berdasarkan hasil penelitian yang dilakukan, dapat disimpulkan hal-hal sebagai berikut :

(1) Perilaku perawat dalam memilah limbah medis termasuk dalam kategori baik, hal ini di dapat dari hasil kuesioner sebanyak 82,5\%. Prosentase tersebut menggambarkan bahwa perawat telah mematuhi prosedur tetap dalam memilah limbah medis. Dengan adanya dukungan sosial baik dari atasan maupun teman sejawat, fasilitas kesehatan serta kebijakan yang mendukung sangat berpotensi terjadinya perilaku yang sesuai dengan peraturan.

(2) Faktor yang paling berpengaruh pada penelitian ini dilihat dari hasil paling besar terdapat pada $\mathrm{X}_{1}$ yaitu niat $=-0,349$ dan $\mathrm{P}=0,027$ dan nilai $\mathrm{R}$ otonomi pribadi $=-$ 
0,003 dan $\mathrm{P}=0,984$. Hal ini bermakna adanya hubungan terbalik antara niat dan otonomi pribadi terhadap perubahan perilaku, dimana ketika niat dan otonomi tinggi maka perubahan perilaku menurun, karena tuntutan perubahan terlalu tinggi dengan menerapkan disiplin dalam pekerjaan dapat melemahkan hubungan stimulus.

\section{SARAN}

Berdasarkan hasil penelitian, peneliti memberikan saran kepada pihak-pihak yang ikut membantu diantaranya adalah sebagai berikut :

\section{Bagi Rumah Sakit Al Islam Bandung}

Dari hasil penelitian bahwa perilaku perawat dalam memilah limbah medis sudah baik. Faktor yang paling berpengaruh terhadap perubahan perilaku adalah niat, pihak Rumah Sakit diharapkan tidak berlebihan dalam memberikan reward dan punishment karena hal ini akan berdampak negatif kepada perubahan perilaku perawat..

2. Bagi peneliti selanjutnya

Karena hasil signifikansi dalam penelitian ini rendah maka disarankan untuk peneliti selanjutnya menelaah kembali kuesioner dan jumlah sampel yang hendak digunakan dan mengembangkan variabel-variabel lain yang memengaruhi perubahan perilaku.

\section{DAFTAR PUSTAKA}

Adisasmito,W. 2012. Audit Lingkungan Rumah Sakit. Jakarta : PT Rajagrafindo persada.

Adisasmito,W. 2010. Sistem Kesehatan.Jakarta : PT Rajagrafindo persada

Adnyaswarin, Nyoman Adinda, I Gusti Ayu Dewi Adnyani. 2017. Pengaruh Dukungan Sosial dan Burnout terhadap Kinerja Perawat Rawat Inap RSUP Sanglah melalui $\quad$ https://ojs.unud.ac.id/index.php/Manajemen/article/view/28874/18523 (30/04/2018)

Anjali Acharya, Anjali, Vasudha Ashutosh Gokhale and Deepa Joshi. 2014. Impact of Biomedical Waste on City Environment: Case Study of Pune, India melalui issue6/D0662127.pdf (26/09/2017).

Bilic, Bojan. 2005. The Theory of Planned Behaviour and Health Behaviours: Critical Analysis of Methodological and Theoritical Issues melalui http://www.pseve.org/journal/upload/bilic2c.pdf (20/10/2017).

BPPAPD.2017. Keadaan Ketenagakerjaan Agustus 2017. Melalui http://bp2apd.jabarprov.go.id/bangun_satenda/keadaan-ketenagakerjaanagusuts-2017/ ((02/12/2017).

Hussain, Mumtaz and Mirza Muhammad Mushtaq. 2014. Awareness about Hospital Wastes and its effects on the Health of Patients in District Dera Ghazi Khan melalui http://journals.abc.us.org/index.php/ajase/article/view/301-308 (30/09/2017).

Kholid, Ahmad. 2012. Promosi Kesehatan. Jakarta : PT Rajagrafindo Persada

Kementerian Kesehatan Republik Indonesia.2015. Profil Kesehatan Indonesia 2015 melalui http://www.depkes.go.id/resources/download/pusdatin/profilkesehatan-indonesia/profil-kesehatan-Indonesia-2015.pdf (22/12/2017).

Teras Kesehatan - 53 
Mohankumar,S and Kottaiveeran. 2011. Hospital Waste Management and Environmental Problems in India. India: Jurnal Pharmaceutical \& Biological Vol 2, $\quad$ No $\quad 6 \quad$ melalui https://www.researchgate.net/publication/258332243_Medical_Waste_Mana gement_and_Control (01/10/2017).

Muchsin, Tukiman dan Eddy Syahrial. Gambaran Perilaku Perawat Dalam Membuang Limbah Medis dan Non medis di Rumah Sakit Umum Daerah Kabupaten Aceh Tamiang Tahun 2013 melalui urnal.usu.ac.id/index.php/kpkb/article/download/1898/1050 (21/07/2017).

Nahal, Syahri Shaumi dan Abdul Latief. 2014. Hubungan Standar Operasional Prosedur, Komunikasi dan Tindakan Terhadap Tingkat Kepuasan Pasien di Ruang Rawat Inap RSUD Labuang Baji Makassar Vol 5, N0 4 melalui ejournal.stikesnh.ac.id/index.php/jikd/article/download/68/19/ (08/01/2018)

Notoatmodjo,S. 2007. Promosi Kesehatan dan Ilmu Perilaku. Jakarta : Rineka Cipta Notoatmodjo,S. 2010. Ilmu Perilaku Kesehatan. Jakarta : PT Rineka Cipta

Nurhidayah, Indah. 2015. Hubungan Pengetahuan, Sikap, dan Ketersediaan Fasilitas dengan Perilaku Perawat dalam Membuang Limbah Medis Padat di RS Bhakti Wira Tamtama Semarang melalui http://lib.unnes.ac.id/27906/1/6411411203.pdf (30/04/2018).

Pandey, Sweta and Anil K Dwivedi. 2016. Nosocomial Infections through Hospital Waste melalui https://www.researchgate.net/publication/299505942_Nosocomial_Infections through_Hospital_Waste. (30/09/2017).

Rahmadita, Irma. 2013. Hubungan antara Konflik Peran dan Dukungan Sosial Pasangan dengan Motivasi Kerja pada Karyawati Di Rumah Sakit Abdul Rivai Berau melalui https://www.google.com/search?q=Rahmadita\%2CI.2013 (6 /09/2017 ).

Riduwan. 2012. Dasar-dasar Statistika. Bandung : Alfabeta

Riduwan dan Engkos.2017.Cara Mudah Menggunakan dan Memaknai Path Analysis (Analisis Jalur). Bandung : Alfabeta

Shareefdeen, Zarook M.. 2012. Medical Waste Management and Control melalui https://www.researchgate.net/publication/258332243_Medical_Waste_Mana gement_and_Control (25/09/2017).

Wexley,K.N.dkk. 1988. Perilaku Organisasi dan Psikologi Personalia. Jakarta : PT Bina Aksara 